\title{
Cytological Studies of Tomato Fruit Rot Caused by Fusarium oxysporum f. sp. lycopersici Race J3 (II) Ultrastructural Differences in Infected Styles of Susceptible and Resistant Cultivars*
}

\author{
Issei Kobayashi**, Miki SAKUrai**, Akira TomiKaWA***, \\ Toshio Yамамото***, Naoto YamaOKA** and Hitoshi KunOH**
}

\begin{abstract}
Factor(s) associated with the degree of resistance of tomato cultivars to the fruit rot caused by Fusarium oxysporum $\mathrm{f}$. sp. lycopersici race $\mathrm{J} 3$ (J3: currently proposed to be revised as $F$. oxysporum f. sp. radicis-lycopersici) were examined by physiological and microscopical means. No significant differences in hyphal growth were found when the fungus was inoculated on the cut surfaces of fruits or in juice of fruits of a susceptible (Mie First) and a resistant cultivar (Zuiken). These results suggest that components of fruits might not be involved in the resistance of the resistant cultivars. Light microscopic observations demonstrated that hyphae grew in styles of both cultivars similarly for the first 4 days after inoculation. Their growth, however, stopped in styles of Zuiken thereafter, but not in Mie First. Thus, some factor(s) in styles of Zuiken might affect the growth of hyphae, leading to the resistance of this cultivar. Electron microscopy revealed that hyphae grew in middle lamellae of conducting tissues of styles. In Mie First, middle lamellae in infected areas of styles were degenerated almost completely by 6 days after inoculation, and thus the remaining cell walls were left arranging side by side. In contrast, middle lamellae and cell walls in infected areas of Zuiken swelled but were not completely degenerated by 6 days after inoculation. These results suggest a possibility that differences of structural and chemical components in styles might account for varied degrees of resistance of both cultivars.
\end{abstract}

(Received November 20, 1989)

Key words: tomato fruit rot, Fusarium oxysporum f. sp. lycopersici race J3, Fusarium oxysporum f. sp. radicis-lycopersici, resistance, ultrastructure.

\section{INTRODUCTION}

The fruit rot of tomato caused by Fusarium oxysporum f. sp. lycopersici race J3 (J3: currently proposed to be revised as $F$. pxysporum f. sp. radicis-lycopersici ${ }^{8)}$ ) was first recorded in Mie Prefecture in 1983, and since then this disease has caused a serious problem in tomato cultivation, especially in the Tokai district. According to Tomikawa ${ }^{13)}$, pathogenic isolates of this fungus which were isolated from rotted fruits are similar in growth characters and pathogenicity to race $\mathbf{J} 3$ of the fungus which has been known to cause browning of vascular bundles and root $\operatorname{rot}^{15)}$. In addition, he ${ }^{13)}$ reported that tomato cultivars which possessed a resistant gene to race $\mathbf{J} 3$ were resistant to the pathogenic isolates. However, the mechanism of resistance of these cultivars is still unknown. In previous paper ${ }^{14)}$ we demonstrated that the present pathogen

* Contribution No. 99 from the Laboratory of Plant Pathology, Mie University

** Faculty of Bioresources, Mie University, Tsu 514, Japan 三重大学生物資源学部

*** Mie Agricultural Technical Center, Ureshino-cho, Ichishi-gun, Mie 515-22, Japan 三重県農 業技術センター 
caused a typical symptom by entering the fruits through their sterigmata, and suggested that some factor(s) in styles might be involved in the resistance. In this paper, we examined growth of the fungus and responses of host tissues in styles of both susceptible and resistant cultivars by light and electron microscopy.

\section{MATERIALS AND METHODS}

Plant and fungus. A susceptible cultivar, Mie First, and a resistant cultivar, Zuiken, of tomato (Lycopersicum esculentum Mill.) were grown from seeds in a glass house. Fruits in the 1st to 3rd flower culsters were used throughout the experiments. A test isolate, 84-S, of F. oxysporum Schl. f. sp. lycopersici race $\mathrm{J} 3$ was cultured on potato-glucose-agar medium at $25 \mathrm{C}$ in the dark for 9 days.

Inoculation. The conidium suspension was prepared by adding sterilized water onto the fungal culture and rubbing the culture surface with a brush. The conidium density was adjusted to approximately $10^{6} / \mathrm{ml}$ with sterilized water. The suspension was sprayed with an atomizer to flowers at flowering days which still attached to plants in a glass house. Inoculated specimens were covered with sealed plastic bags, and the bags were removed $24 \mathrm{hr}$ after inoculation.

Growth of hyphae on the cut surfaces of fruit or in fruit juice. To examine whether the components of fruits can explain a difference in the degree of resistance of both cultivars, the fungus was inoculated to either the cut surfaces of fruits or fruit juice of both cultivars.

Fruits of 4-6 cm diameter of both cultivars were cut into halves with a sterilized knife. A mycelial disc of $8 \mathrm{~mm}$ diameter which had been obtained from the 4-day culture plate with a cork borer was placed on the cut surface of each fruit. The inoculated fruits were incubated in a moist petri dishes at $25 \mathrm{C}$ for 3 days.

Similar fruits were harvested from both cultivars and washed with deionized water. After removing sepals, they were homogenized with deionized water of which weight was equivalent to that of the respective fruits, using a mixer. The homogenate was filtered with double cheese clothes to remove fruit debris and centrifuged at $38,000 \times \mathrm{g}$ at $0 \mathrm{C}$ for $10 \mathrm{~min}$. The supernatant was added with glucose at $2 \%(\mathrm{w} / \mathrm{v})$, and then filtered with a microfilter $(0.22 \mu \mathrm{m}$ pore size). The final sterilized supernatant inoculated with $0.5 \mathrm{ml}$ of the above conidium suspension was then shaken-cultured at $25 \mathrm{C}$ in the dark. After cultured for 3 days, mycelia in each flask were harvested and their dry weight was recorded after drying at $70 \mathrm{C}$ for $24 \mathrm{hr}$.

Microscopy. At 2, 4 and 6 days after spray-inoculation, styles which had been detached artificially from inoculated flowers were fixed with an FAA fixative for light microscopy and by the tannic acid method for scanning electron microscopy, followed by the same preparation and observation procedures as described in previous paper ${ }^{14)}$. To compare the growth of hyphae in styles of both cultivars, the length of hyphae which elongated farthest from the sterigma was measured in serial sections of a style with a low power of light microscope equipped with a micrometer.

\section{RESULTS}

\section{Growth of hyphae on the cut surfaces of fruits and in fruit juice of both cultivars}

Mycelia grew similarly on the cut surfaces of fruits of both cultivars. In spite of the active growth of mycelia, typical symptoms such as browning and/or blister did not appear on fruits of both cultivars for 3 days after inoculation. Moreover, dry weight of mycelia cultured was $0.075 \pm 0.003 \mathrm{~g}$ per flask for Mie First and $0.080 \pm 0.004 \mathrm{~g}$ for Zuiken. There was no significant difference between both weights $(0.5<P)$. 


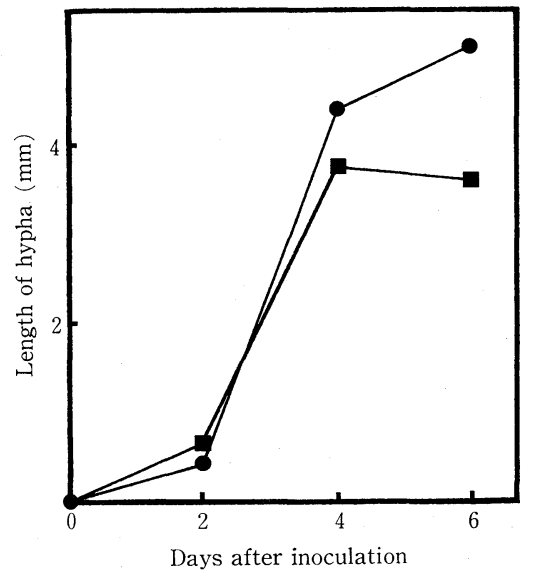

Fig. 1. Growth of hyphae of Fusarium oxysporum f. sp. lycopersici race J3 in styles of Mie First (a susceptible cultivar, - ) and Zuiken (a resistant cultivar, $\mathbf{a}$ ) for 6 days after inoculation. Growth of hyphae was evaluated by measuring the length of the longest hypha elongating from the sterigma.

\section{Growth of hyphae in styles of both cultivars}

Light microscopy of paraffin-embedded specimens demonstrated that hyphae stained dark violet and tissues of styles stained orange except blue vascular bundles by the Stoughton's double stain method. As shown in Plate I-1 and 2, hyphae entered the styles through a sterigma and elongated into the inside of styles in both cultivars. The length of the longest hyphae elongating from the sterigma was $0.42 \pm 0.26 \mathrm{~mm}$ on average at the $2 \mathrm{nd}$ day after inoculation, and $4.40 \pm$ $0.11 \mathrm{~mm}$ and $5.10 \pm 0.22 \mathrm{~mm}$, respectively, at the 4th and 6th days in styles of Mie First. In contrast, that in styles of Zuiken was $0.64 \pm 0.26 \mathrm{~mm}, 3.75 \pm 0.26 \mathrm{~mm}$ and $3.60 \pm 0.31 \mathrm{~mm}$, respectively, at the 2nd, 4th and 6th day (Fig. 1). There were no significant differences in the length of the longest hyphae in both cultivars for the first 4 days after inoculation $(P=0.01)$ but both values at the 6th day differed significantly $(0.1<P<0.2)$.

\section{Ultrastructural differences in features of infected styles of both cultivars}

Almost all hyphae growing in styles were found in conducting tissues which were located in the central part of styles. In the tissues of uninfected, young styles of both cultivars, long cells with a compact cytoplasm were connected tightly by middle lamellae of 0.2 to $1.0 \mu \mathrm{m}$ width (Plate I-3, 4). Electron-transparent cell walls encompassing the cells and highly electron-dense middle lamellae were readily distinguished by their electron density (Plate I-3, 4). When the specimens prepared 2 days after inoculation were observed, almost all hyphae were found in middle lamellae of the conducting tissues (Plate II-1, 2). Middle lamellae of Mie First where hyphae grew, turned granular and their electron density was reduced (Plate II-1). Neighboring cells around such middle lamellae were occupied by large vacuoles. Similar changes of middle lamellae were often observed in Zuiken, but in some middle lamellae a large number of vesicular structures delimited by a membrane were observed adjacent to the hyphae (Plate II-2). These vesicular structures contained an electron-dense center with a thin electron-transparent margin. Middle lamellae where such structures were present, remained electron-dense as similarly as those of uninfected controls. These unique vesicular structures were hardly observed in infected areas of styles of Mie First.

A larger number of hyphae were found in middle lamellae of styles of both cultivars prepared at the 6th day after inoculation (Plate II-3). As seen in Plate II-3, cytoplasm of most conducting cells of Mie First seemed to be degraded and crushed in infected areas, and thus the remaining cell walls arranged side by side. In this case, middle lamellae seemed to be de- 
graded almost completely. In contrast, middle lamellae of Zuiken where hyphae grew, abnormally swelled as shown in Plate II-4. They turned granular and reduced their electron density. The cells adjacent to middle lamellae where hyphae grew seemed to be degraded with highly electron dense cytoplasm of hardly distinguishable organelles (Plate II-4). In these cells, cell walls also seemed to swell, and thus the borders of cell wall and middle lamella became indiscrete (Plate II-4).

As far as we observed, there was only one case that hyphae grew in vascular bundles of Mie First. Such a case never happened in Zuiken. There were no visible differences in ultrastructure of hyphae growing in styles of both cultivars until the 6th day after inoculation, although some hyphae appeared degenerating.

\section{DISCUSSION}

In previous paper ${ }^{14)}$ we suggested that the degree of resistance to the present disease among cultivars of tomato might be associated with some factor(s) in styles. In addition to the previous results showing a low possibility of the fungal penetration through the fruit and style surfaces other than sterigmata, the present results that components of fruits might not be related to the resistance mechanism, further support our previous conclusion ${ }^{14)}$.

In some diseases caused by Fusarium spp., hyphae reach vascular bundles after penetration and grow actively there ${ }^{2,5,10)}$. In the present disease, however, hyphae grew in conducting tissues of styles and seldom in vascular bundles. As similarly as $F$. oxysporum f. sp. cucumeri$n_{u m^{10)}}$, the present fungus obviously degenerates middle lamellae of styles which are probably composed of pectins, thus suggesting that this fungus secretes pectolytic enzymes. Fusarium oxysporum f. sp. lycopersici has been often reported to produce pectolytic enzymes ${ }^{1,6,9}$. When plant cell walls are degenerated by degradative enzymes of attacking fungi, they usually become swollen $^{3,4,7,11,16)}$. Interestingly, cell walls including middle lamellae of Zuiken were prominently swollen when attacked by the present fungus, while in Mie First middle lamellae of infected areas were degraded almost completely, leaving electron-transparent cell walls arranging side by side. As demonstrated in Fig. 1, hyphal growth was obviously retarded in styles of Zuiken between 4 and 6 days after inoculation. Moreover, in middle lamellae of Zuiken, unique vesicular structures delimited by a membrane appeared in infected areas. These observations suggest that middle lamellae of both cultivars might be different in some way. Such a difference might become a limiting factor of hyphal growth in styles of Zuiken, leading to the resistance of this cultivar.

Shinohara ${ }^{12)}$ suggested tha: in Ustilago tritici and wheat cultivar combinations there might be a close relationship between mucilagenous substances secreted from sterigmata and cultivar resistance. Our preliminary tests revealed that conidia of the present fungus well-germinated on sterigmata of both susceptible and resistant cultivars, and it was also confirmed by scanning electron microscopy (unpublished) that there were no structural differences in sterigmata of both cultivars which could account for the differences of the degree of resistance between both cultivars. Thus, all these observations strongly suggest that factor(s) affecting the degree cf resistance might be present in styles. However, the possibility can not be ruled out that differences of hyphal growth and ultrastructural feature in both cultivars might be simply ascribed to the fact that physiological senescence occurs in styles of Zuiken much earlier than those of Mie First ${ }^{14)}$.

A further biochemical analysis of styles is certainly required for studying the resistance mechanism for the present disease. 


\section{Literature cited}

1. Bateman, D.F. and Millar, R.L. (1966). Ann. Rev. Phytopathol. 4: 119-146.

2. Beckman, C.H. and Zaroogian, G.E. (1967). Phytopathology 57: 11-13.

3. Chou, C.K.S. (1978). Physiol. Plant Pathol. 13: 189-192.

4. Horino, O. and Akai, S. (1968). Ann. Phytopath. Soc. Japan 34: 51-55.

5. Hutson, R.A. and Smith, I.M. (1980). Physiol. Plant Pathol. 17: 245-257.

6. Jones, T.M., Anderson, A.J. and Albersheim, P. (1972). Ibid. 2: 153-166.

7. Kenning, L.A. and Hanchey, P. (1980). Phytopathology 70: 988-1004.

8. Komada, H., Yamamoto, I., Kuniyasu, K., Saito, M. and Ezuka, A. (1989). Shokubutsu bōeki (Plant Protection) 43: 645-646.

9. Langcake, P. and Drysdale, R.B. (1975). Physiol. Plant Pathol. 6: 247-258.

10. Matuo, T., Komada, H. and Matsuda, A. eds. (1980). Fusarium Disease of Cultivated Plants. Zenkoku Noson Kyoiku Kyokai Pub. Co. Ltd., Tokyo.

11. Mills, J.T., Caeseele, L.V. and Gillespie, R. (1982). Can. J. Plant Pathol. 4: 19-26.

12. Shinohara, M. (1976). Rev. Plant Protec. Res. 9: 124-142.

13. Tomikawa, A. (1987). Shokubutsu bōeki (Plant Protection) 41: 56-61.

14. Tomikawa, A., Kobayashi, I., Sakurai, M., Yamamoto, T., Yamaoka, N. and Kunoh, H. (1990). Ann. Phytopath. Soc. Japan 56: 265-268.

15. Ui, T. ed. (1983). Soil-borne Diseases of Cultivated Crops in Hokkaido, Buneido, Tokyo.

16. Wheeler, H. (1977). Physiol. Plant Pathol. 11: 171-178.

\section{和 文 摘 要}

小林一成・桜井美樹・冨川 章・山本敏夫 - 山岡直人・久能 均 : Fusarium oxysporum f. sp. lycopersici レース J3 に起因するトマト果実腐敗症の細胞学的研究 (II) 感受性预よび抵抗性品種の感染花柱の微細構造

Fusarium oxysporum f. sp. lycopersici レース J3 を感受性拉よび抵抗性トマト品種の果実切断面および果 汁に接種したが, 両品種間で菌䒺生長に差はなかった。両品種の花の柱頭に胞子を接種したところ, 接種後 4 日間は柱頭から侵入した菌糸の生長に両品種間で差はなかったが，抵抗性品種では以後の生長は停止した。 電顕観察によると, 両品種の花柱内では菌系は細胞間中層を伸長した。感受性品種では, 菌糸が伸長してい る中層は接種後 4 日目までに顆粒化し，6日目までにほぼ完全に消失した。また，6日目までに感染部位の 花柱細胞質は変性し，圧縮されて，細胞壁のみが残っていた。抵抗性品種では，4 日目までに，菌糸に隣接 する中層に特異的な小囊状構造が出現し，6日目までに中層が異常に膨潤した。これらの結果は，抵抗性品 種の抵抗性が花柱中層の構造的, 化学的特殊性に関係していることを示唆している。

\section{Explanation of plates}

\section{Plate I}

1. Hyphae elongating from a sterigma of Mie First, 2 days after inoculation. $B a r=10 \mu \mathrm{m}$.

2. Hyphae elongating from a sterigma of Zuiken, 2 days after inoculation. Bar $=10 \mu \mathrm{m}$.

3. Long cells of a style of Mie First, connected by an electron-dense middle lamella. Bar $=2 \mu \mathrm{m}$.

4. Long cells of a style of Zuiken. An electron-dense middle lamella and cell wall of low electron density are readily distinguishable. $B a r=2 \mu \mathrm{m}$.

Plate II

1. A hypha elongating in a middle lamella of Mie First, 4 days after inoculation. Middle lamella adjacent to the hypha has turned granular, suggesting that pectic substances constituting the middle lamella have been degraded by pectolytic enzymes secreted from the hypha. $\operatorname{Bar}=2 \mu \mathrm{m}$.

2. Hyphae growing in middle lamellae of Zuiken, 4 days after inoculation. Unique, vesicular structures have appeared adjacent to the hyphae in the middle lamellae. $B a r=2 \mu \mathrm{m}$.

3. Hyphae growing in a style of Mie First, 6 days after inoculation. The host cytoplasm in the infected area has been degraded almost completely and turned extremely electron-dense. Some host cells have been crushed, leaving cell walls arranging side by side. $\operatorname{Bar}=2 \mu \mathrm{m}$.

4. Swollen middle lamellae adjacent to growing hyphae in a style of Zuiken, 6 days after inocula- 
tion. Host cells have turned electron-dense. Electron density of middle lamellae has been reduced, and thus the border between cell wall and middle lamella became indiscrete. $\quad$ Bar $=1$ $\mu \mathrm{m}$.

Abbreviations: $\mathrm{CL}$, chloroplast; $\mathrm{CW}$, host cell wall; $\mathrm{CY}$, host cytoplasm; ML, host middle lamella; $\mathrm{N}$, host nucleus; V, host vacuole; VS, vesicular structure; $h$, fungal hypha. 
Plate I

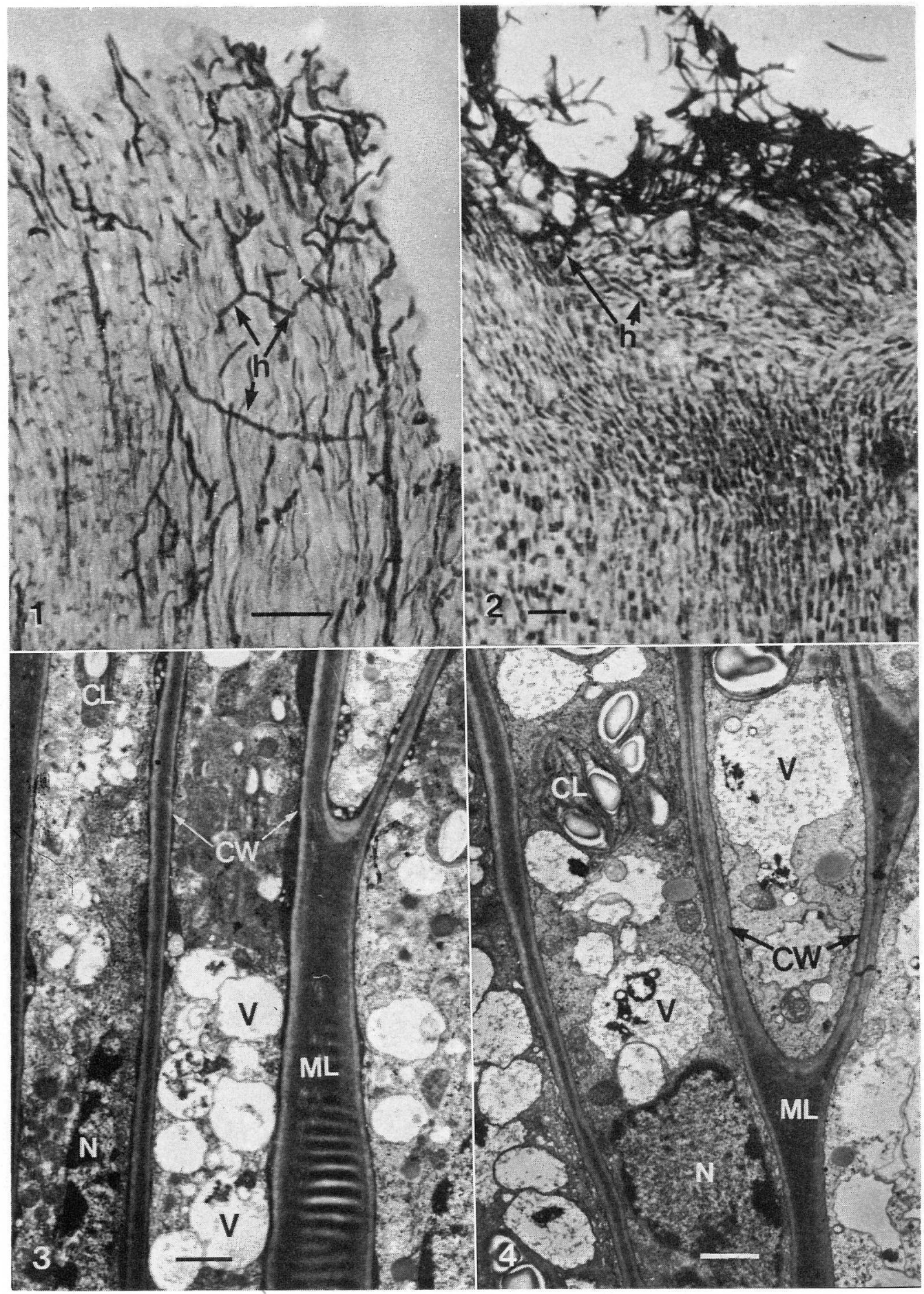


Plate II

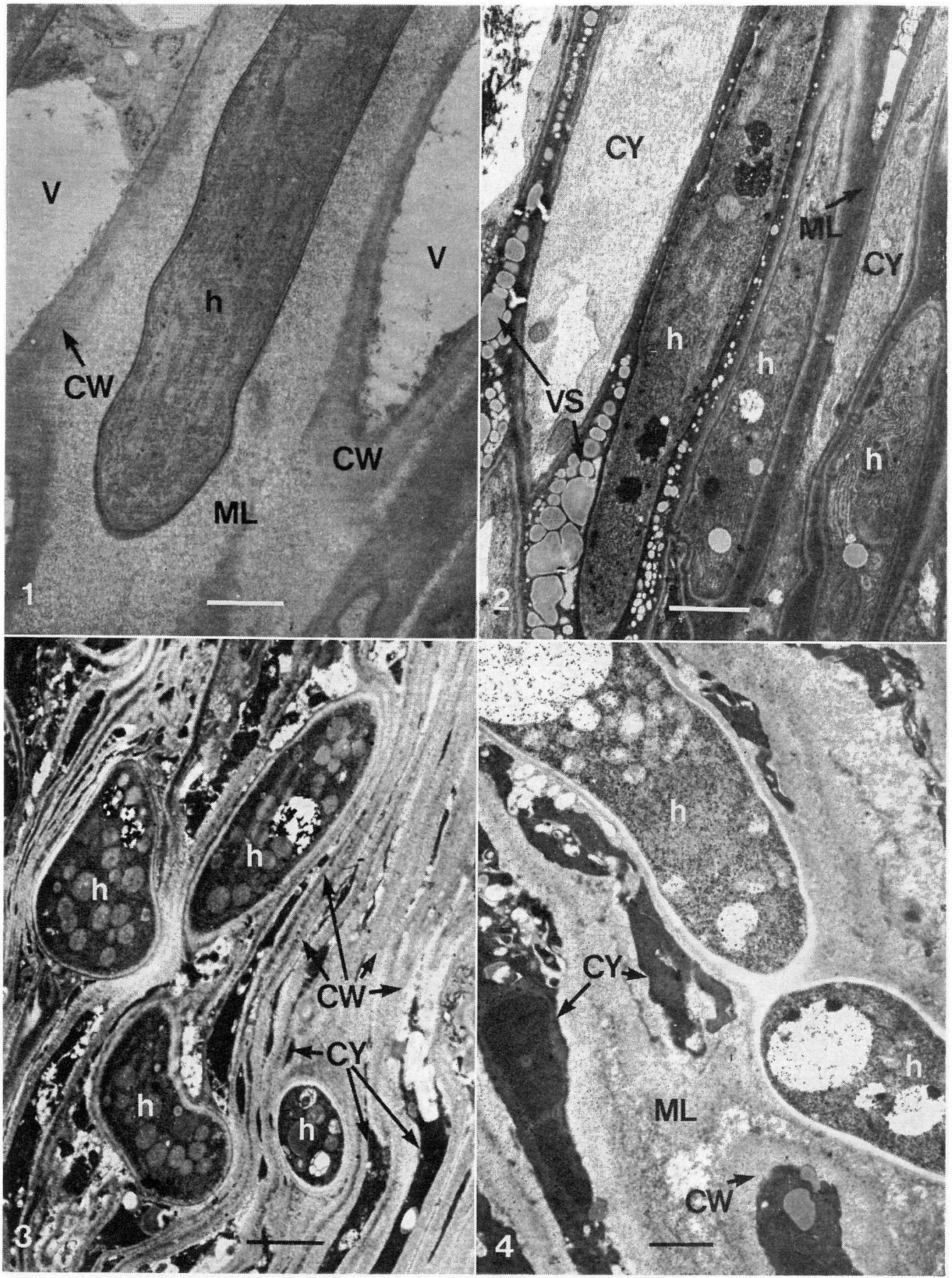

